\title{
Ambrose and Augustine \\ Two Bishops on Baptism and Christian Identity
}

Reidar AasgaArd

\section{Introitus in Milan}

In the middle of the night before 25 April 387, a group of people were present in one of the many churches in Milan, the city which at that time was the administrative and political capital of the Roman Empire. The church may have been the cathedral, the huge Basilica Nova, just a minute's walk away from the city centre, or one of the very recently erected churches along the main roads leading into the city. ${ }^{1}$ The people were gathered in the baptistery, the section of the church often called the Holy of Holies, taking its name from the place which was thought to prefigure it, the inner sanctuary of Israel's Temple in Jerusalem. ${ }^{2}$

Before this night, each person had gone through an individual and communal process. They had - some for a short while, others for several years been catechumens, awaiting baptism, through which they would become members of Christ and his church. Now, during the last months, since Epiphany, they had been competentes - "askers" who after having handed in a petition to be baptized had been preparing for the event in an introductory course on Christian faith and living. And now on the most holy night, the Easter vigil, they were - young and old, women and men - taking part in the sacred rite of baptism. Through this sacramental mystery they would become neophytes, newborn Christians, but still - as infantes - in need of protection and further maturing in their faith and lives. ${ }^{3}$

1 See N. B. McLynn, Ambrose of Milan, 226-237. W. Harmless, "Baptism," 85 holds that it probably was the Basilica Nova.

2 See Myst. 5; Sacr. 4.1-4.

3 For an introduction to Ambrose's liturgical praxis and theology of baptism, see E. FERGUSON, Baptism in the Early Church, 634-647 (ch. 40); also TH. M. FInN, Early Christian Baptism and the Catechumenate, 57-76. For a detailed presentation, see H. M. RILEY, Christian Initiation. Riley's work is a comparative study of baptism in Cyril of Jerusalem, John Chrysostom, Theodore of Mopsuestia, and Ambrose. The book has a number of helpful synoptic charts of their pre-baptismal, baptismal, and post-baptismal practices, highlighting both similarities and differences. For an interesting discussion of the praxis of baptism at Easter, see P. F. BRADSHAW, "Diem baptismo sollemniorem". He argues that the idea in liturgical scholarship of an early Christian $\left(3^{\text {rd }}-4^{\text {th }}\right.$ century) preference for paschal baptism is untenable, and that it was prima- 
Of the people present this night, four are known to posterity. One was the person responsible for performing the baptism, the bishop Ambrose (ca. 340 397), who was then at the height of his fame and power as church leader. The three others were among the petitioners: the life-long friends Alypius and Augustine (354-430), and the son of the latter, the fifteen-year-old Adeodatus. The youngster died only two years later, but both Alypius and Augustine were to end up as bishops in their North African homeland. Augustine was unwillingly elected priest in Hippo already four years after his baptism. And four years later, in 395, he became the city's bishop. From then on and for more than thirty Easter vigils, he would himself guide ever new petitioners through the sacred rite of baptism. ${ }^{4}$

In a sixteen-line poem, Ambrose, who wrote several hymns, has given a condensed description of central features in his understanding of baptism. The poem was clearly intended as an inscription in a baptistery. It is known to have been placed around the font in San Giovanni alle Fonti in the church of St. Thecla when it was rebuilt at the end of the fifth century, but may also have had a similar place when Ambrose during his years as bishop ordered the building of this church in Milan. The latter half of the text has this to say about what happens in the font: ${ }^{5}$

Here, whoever wants the sins of a shameful life to lay aside, may bathe the heart strings and have a pure soul. To this place may they eagerly come: however dark he may be who has the courage to approach, he departs whiter than snow. To this place may they hurry to be holy: without these waters no one is holy, in them is the kingdom and counsel of God, the glory of righteousness. What is more divine than this, that in a brief moment the guilt of the people perishes.

In his famous autobiography, Confessiones, written about twelve years after his baptism, Augustine recaptures the effect the event had on him, and the importance he ascribed to it looking back on his former life: ${ }^{6}$

rily a local custom in the Roman and North African churches in the latter half of the $4^{\text {th }}$ century. If so, it can be seen as an (unsuccessful) attempt on the part of Ambrose, Augustine, and some of their colleagues to establish a tradition of Easter baptism in the West. See also M. E. JoHnson, "Christian Initiation," esp. 702-704, 706-707 for a discussion of these matters.

4 In Hippo, Augustine developed his own baptismal liturgy; on this, see Ferguson, Baptism, 778-789.

5 See the translation and comments in Ferguson, Baptism, 638; Latin text in G. B. De Rossi, Inscriptiones christianae urbis Romae (Vol. 2/1), 161.

6 Conf. 9.6.14. Translation is from Augustine, The Confessions (The Works of St. Augustine), 219-220. Augustine does not say in The Confessions that he was baptized by Ambrose, but he mentions this in a letter (Ep. 147.52). 
And so we were baptized, and all our dread about our earlier lives dropped away from us. During the days that followed I could not get enough of the wonderful sweetness that filled me as I meditated upon your deep design for the salvation of the human race. How copiously I wept at your hymns and canticles, how intensely was I moved by the lovely harmonies of your singing Church! Those voices flooded my ears, and the truth was distilled into my heart until it overflowed in loving devotion; my tears ran down, and I was the better for them.

The texts of the two bishops are very different, not least due to their disparate genres, but also since they reflect characteristics of each author. Still, the texts have important features in common. The most salient is their emphasis on baptism as an existential turning point. Their descriptions of the consequences of baptism make it clear that both Ambrose and Augustine consider it an event in which a drastic re-orientation of life takes place, a crisis which brings about a fundamental shift of self-perception and status for those involved.

Ambrose, for his part, states this most pointedly in the formulation, "however dark he may be who has the courage to approach, he departs whiter than snow". But he also visualized the change in the Milan baptismal rite itself, in which the baptizands first stood facing west while renouncing the devil and their old ways, and then turned to the east confessing Christ and their new life. $^{7}$

Augustine, on the other hand, in his description works out in considerable detail the impact baptism made on him. He tells us nothing about the event itself, however, but all the more about the strong psychological effect it had on him, particularly during the following days: in his own words, "all our dread about our earlier lives dropped away" and he was filled with "wonderful sweetness". Thus, amidst all the dissimilarities, both Ambrose and Augustine each in his own way here testify to baptism as an event that in fundamental ways affects a person's identity as a human and as a Christian believer.

\section{Baptism and Identity in Ambrose and Augustine}

This article will focus on baptism as a vital phase of transition, and how this phase is depicted by Ambrose and Augustine. Important questions will be: what do the two bishops communicate to their audiences about the meaning and implications of baptism for faith and life? In what ways can they be seen as trying to construct a new identity in the neophytes? What means do they make use of in order to shape such an identity? And what does this Christian identity look like? My intention here is not to give an exhaustive answer to these questions, but rather to indicate how the issues of baptism and identity belong together, and how this finds expression in these two central early Christian figures.

7 Cf. Myst. 7, and below. 
Both Ambrose and Augustine, especially the latter, have much to say about baptism in their writings. To survey this is impossible within this article, and several scholars have already dealt with it at length. ${ }^{8}$ Here, my focus will be much narrower: I shall limit myself to a few texts, namely sources that are immediately linked to the event of baptism. With Ambrose, this will be his The Sacraments and The Mysteries; with Augustine, it will be sermons preached at the Easter vigil and during the following days. In both cases, the material closely reflects the message that was mediated to the neophytes at this central juncture in their lives. Due to the genre and setting of the texts, some aspects of baptism that were important for one or both of them will only be hinted at and even omitted - still, some will occasionally turn up, if only in passing. ${ }^{9}$ In analyzing the material, I shall deal with a broader spectrum of elements than has often been taken into account, and pay special attention to how Ambrose and Augustine make use of and combine such elements.

Studying Ambrose and Augustine together is of interest, since their lives also intersected on other occasions than at the baptism of the latter. As is well known, Augustine in his Milan years (384-387) regularly attended Ambrose's church services: he admired the bishop's personality and learning, and was influenced by him in a number of ways. This can be seen in Augustine's Cassiciacum dialogues, in the Confessiones, and in his exegesis, preaching, and liturgical practice. They were also a few times in personal contact. ${ }^{10}$ This joint history makes it more convenient to compare the two with regard to how they make use of baptism as a means for identity construction - and probably also makes such a comparison more compatible. The point in presenting them together here, however, is not to trace the influence of Ambrose on Augustine. ${ }^{11}$ My aim is more modest: to juxtapose the two in order to see their distinctive profiles more clearly, not least by observing how and to what extent they differ in emphasis and approach.

8 For updated presentations with many references see Ferguson, Baptism (chs. 40 and 51-52) and several of the entries in A. D. Fitzgerald, Augustine Through the Ages, esp. W. Harmless, "Baptism" (also "Catechumens, Catechumenate", "Sacraments"); also J. P. Burns' contribution in this publication.

9 Some such aspects are infant baptism, the relation between faith and baptism, and the fate of martyrs who died before their baptism. - In recent years, sermons and other homiletic material have received more scholarly attention and have been accorded much more value as sources for the theology, thinking and social praxis of early Christianity, cf. the research survey in W. MAYER, "Homiletics”, esp. 567-568. Thus, as far as the issue of Christian identity is concerned, these works by Ambrose and Augustine are of great interest.

10 Cf. e.g. Beat. 1.4; 4.35; Solil. 2.14.26.

11 For such discussions, see Harmless, Augustine and the Catechumenate, 79-105; PH. Rousseau, "Augustine and Ambrose". The influence of Ambrose on Augustine has often been exaggerated, however; here, I agree with J. P. Burns, “Ambrose Preaching to Augustine," esp. 379-381; McLynn, Ambrose of Milan, 240-243; McLynn, “Ambrose of Milan," 18-19. 


\section{Identity and Identity Construction}

Before turning to the material, we need to touch on the concept of identity. What do I mean by this, and how does the construction of identity, and Christian identity, take place? The issue of identity has been a focus of general interest within research in the last couple of decades. As has been amply shown, the identity of an individual is made up of a variety of elements related to psychology, social context, physical condition, geography, and culture. The elements often differ in form and content, and are in constant interplay and frequently in conflict with one another. Thus, it is problematic to speak of identity as a fixed reality; rather, it is a relatively fluid and elusive matter. Still, I find the concept useful in relation to baptism, our topic of interest, although I cannot deal with it in any depth here. Thus, I shall speak of identity in a rather broad sense, and as a construct, not as some kind of given fact. What I want to focus on is the kind of identity Ambrose and Augustine try to evoke in their preaching related to the rite of baptism, not the effect that their message may have had on their audiences.

The question of identity has for some time also been an issue in research into late antiquity, the time of our characters, and the reflections above hold true for this period as well. ${ }^{12}$ As has been suggested by scholars, late antiquity was marked by a transformation in which there was, as summarized by Richard Miles, an "increased openness and mobility in realigning and reappropriating older paradigms", and "a novel, self-consciously revisionist perspective to constructions of identity and culture". ${ }^{13}$ Within this process, fourth- and fifth-century Christianity - with its marked growth and efforts at consolidation - was without doubt a main factor in the construal of identity, whether individual or communal. ${ }^{14}$ During these centuries, the Christian movement established itself as what in retrospect can be viewed as an all-encompassing type of religion, involving a broad spectrum of what we perceive to be identity-shaping factors.

In his respected description of the modern world religions, Ninian Smart lists seven dimensions to what characterizes them. ${ }^{15}$ Although these dimensions can be very differently configured internally as well as vis-à-vis one another, taken together they serve as powerful means in the shaping of identity, and religious identity in particular. In what follows, I shall apply these catego-

12 See R. Miles, Constructing Identities in Late Antiquity, especially IDEM, "Introduction," 1-4, and S. HARrison, "Autobiographical Identity and Philosophical Past in Augustine's Dialogue De Libero Arbitrio"; also S. A. Harvey/D. G. Hunter, The Oxford Handbook of Early Christian Studies (Part III. Identities); V. Burrus, Late Ancient Christianity (Part 3. Identity at the Boundaries); S. Bell and I. L. HANSEN, Role Models in the Roman World: Identity and Assimilation.

13 Miles, "Introduction," 4, 10-11.

14 See Miles, "Introduction," 5, who also emphasizes two other factors, namely the changes in imperial self-presentation and ideology and the growing importance of "barbarians" in the empire's military and civil structures.

N. Smart, The World's Religions. 
ries as tools for analysing my material. Obviously, the approach is methodologically simplistic, but nonetheless useful as a means for sketching the profiles of Ambrose and Augustine concerning baptism and identity. ${ }^{16}$

Smart's seven dimensions are: doctrinal (philosophy, theology), narrative (sacred stories, texts), ethical (values, morality), ritual (liturgy, sacramental acts), experiential (experiences, emotions), material (buildings, sacred items), and social (institutions and social relations). ${ }^{17}$ Below I shall touch on all of these and deal particularly with three: the doctrinal (theology of baptism), the narrative (use of the Bible), and the social dimension (relations to oneself and others). ${ }^{18}$ The last dimension I define more broadly than Smart, by also including relations to outsiders: in the shaping of identity, a central factor is how persons or groups relate to others: self is also defined through negation, by setting up various kinds of "others" as contrasts to oneself. ${ }^{19}$ As we shall see, such a boundary marking is important as a means in the construction of identity in both Ambrose and Augustine. A detailed analysis of the dimensions and their interrelations in this material is impossible here, however; the following will have to serve as an impressionistic sketch.

\section{Ambrose's The Sacraments and The Mysteries}

The Sacraments (De sacramentis) is a series of six brief sermons preached in the days after baptism at the Easter vigil, during the so-called Octave of Easter. ${ }^{20}$ The series consists of explanations and instructions aimed at the neophytes about the meaning and implications of baptism. The sermons follow a specific thematic outline, though not in a strict way. The Mysteries (De mysteriis) is a briefer and far more polished product dealing largely with the same issues. ${ }^{21}$ Whereas the former work may be a "printout" on the basis of a stenographer's notes, possibly published without Ambrose's reworking, the latter is likely to have passed through

16 In doing this, I will have to exclude factors that serve in crucial ways to shape identity on a more general level, such as perceptions of the past (history), of body and gender (anthropology), and of social relations (e.g. family). The central place of baptism and of the other rites and elements accompanying it for the shaping of early Christian identity is strongly underscored also in R. M. Jensen, "Baptismal Rites and Architecture," 117-118.

17 SMART, World's Religions, 10-21.

18 However, I do not always distinguish clearly between them (especially the first two dimensions).

19 See also Miles, "Introduction," 6. I make a similar analysis in R. AAsGAARD, "Among Gentiles, Jews, and Christians: Formation of Christian Identity in Melito of Sardis".

20 For a broad and thorough presentation of Ambrose, see F. H. DudDEn, The Life and Times of St. Ambrose (2 vols.). For more recent and succinct presentations, see B. Ramsey, Ambrose and McLynn, Ambrose of Milan. Citations in English from The Sacraments are from Ambrose, Theological and Dogmatic Works (FC 44).

21 Citations in English from The Mysteries are from RAmsey, Ambrose. 
the redactional hand of Ambrose himself. Both works probably originated about 390-391 and have so many common traits in both structure and content that they appear to reflect quite closely his preaching in subsequent years. ${ }^{22}$ What Ambrose preaches here may have been very similar to what Augustine heard as an infans only three or four years earlier.

The Sacraments and The Mysteries are extremely important from the point of view of catechetical and liturgical history, not least since Ambrose's description makes it possible to reconstruct the sequence and contents of the baptismal ritual in considerable detail. ${ }^{23}$ Here, however, I deal only with aspects relevant to identity construction. For simplicity's sake, I shall use only the most detailed number system in the references below.

More than half of The Mysteries (1-42) deals with baptism. The Eucharist occupies just a few sections (Myst. 43-44), and aims primarily at two things: arguing the primacy of age of the Christian sacraments (Myst. 45-49) and the transforming power of the divine word on the nature of the elements (bread and wine; Myst. 50-57). The pattern in The Sacraments is much the same. The first three sermons and some of the fourth develop on the ritual of baptism and its meaning. The Eucharist is dealt with in the rest of the fourth and the beginning of the fifth sermon, whereas the main part and the whole of the last sermon consist of an exegesis of the Lord's Prayer. What is mediated to the neophytes, then, is primarily what Ambrose sees as the meaning and consequences of baptism, in what ways it has changed their lives and will continue to reform it. The function of the Eucharist and prayer is mainly to carry on what has already been laid down in baptism. However, much of what Ambrose has to say about the Eucharist, such as the relationship between the divine word and the sacramental element, is equally applicable to baptism. Thus, the emphasis that Ambrose gives to baptism as a fundamental marker of Christian identity is obvious.

\section{Ambrose on Baptism and Christian Identity}

In his works, we can see how Ambrose in his efforts at identity construction makes use of all the dimensions outlined above. ${ }^{24}$ He develops in considerable

22 On the dating, see Ramsey, Ambrose, 62-63, 145-46.

23 See especially Riley, Christian Initiation; also Finn, Early Christian Baptism, 59-62. But see also HarmLEss, Augustine and the Catechumenate, 106 for references to other catechetical material in Ambrose. JoHnson, "Christian Initiation," 202-203 stresses diversity and variety as a characteristic of early Christian initiation practices and warns against seeing any one particular ritual as representing a standard; for examples of similarities and differences, see the synoptic charts in RILEy, Christian Initiation.

24 For a discussion of the more general aspects of identity construction in Ambrose, see McLynN, Ambrose of Milan, esp. chapter 5. Ambrose does nowhere speak of his own baptism. 
detail the theological aspects of baptism, takes the intellectual objections of his audience seriously, and puts much energy into discussing such matters (Myst. 8 ; 19; 25-26; 50; Sacr. 3.13-14). No wonder that this was one of the qualities of Ambrose's preaching which appealed to Augustine. The Bible with its narratives and instructions also plays a central role, with the reading of biblical texts accompanying many of the ritual elements in the baptismal rite.

At the same time, Ambrose also addresses his audience on an emotional level - his intense and detailed exegesis of the Song of Songs is testimony to this (Myst. 35-41; 55-58; Sacr. 5.5-17). He frequently refers to specific elements in the rite of baptism and explains their meaning step by step, such as anointing (Myst. 29; Sacr. 2.24; 3.1), the dressing in white garments (Myst. 34), and "a spiritual seal" (Myst. 42). An interesting example is the practice mentioned above of turning from the west to the east: from the devil and one's past deeds and towards the risen Christ and one's new way of living (Myst. 7). On various occasions he also refers to and makes interpretations of details of the interior of the basilica, such as the lamps and the use of incense (e.g. Myst. 17; 19). ${ }^{25}$

Several times, Ambrose points to the consequences of baptism for Christian living. On this, however, his admonitions are mostly unspecific: the neophytes are to display simplicity and humility (Myst. 25; 31; 33), bear good fruits (Myst. 56-57), and to prefer eternal life to temporal life (Sacr. 2.24). Rather than offering concrete advice, Ambrose appears to aim at moral formation of a rather general kind (cf. Sacr. 3.12; 3.15). Finally, Christian identity is in a number of ways related to the social dimension, for example through the neophytes' place in the Christian community, vis-à-vis the clergy, and towards people outside but to this we shall return below.

\subsection{Theology of Baptism}

When he sets out to present the rite of initiation and to unravel its meaning, Ambrose explicitly takes on the role of a mystagogue, whose aim is to protect the mystery from being violated. ${ }^{26}$ Already at the start of The Mysteries, he states

25 Cf. also the description in the first half of Ambrose's baptistery inscription (Ferguson, Baptism, 638):

With eight chapels [niches] the temple rises high for holy use, the font is eight-cornered, which is appropriate for its gift.

With this number [eight] it was fitting the hall of holy baptism to erect, by which true salvation returned to the peoples

in the light of the rising Christ, who releases from the prison of death and raises up the dead from their graves,

and freeing from the stain of sin the guilty who make confession, he washes them with the clear flowing water of the font.

26 On the mystagogical background, see JoHnson, "Christian Initiation," 705; also Riley, Christian Initiation. 
that telling the petitioners about the meaning of the sacraments before they themselves had participated, would make him one of the "betrayers rather than explainers" of these mysteries (Myst. 2). At the end of the work (Myst. 55-56) he elaborates this and justifies the secrecy by referring to Song of Songs 4:12, "A garden locked is my sister, my bride, a garden locked, a fountain sealed", where he interprets the "locked garden" and the "sealed fountain" as descriptions of the church. Ambrose emphasizes this further by insisting that in Christianity faith has primacy before understanding: "it was better that the light itself of the mysteries be poured into you when you were without any previous knowledge than that discussion of some kind anticipate them" (Myst. 2; also Sacr. 1.1). By presenting baptism in this way, he also ascribes to his audience a special privilege: they are deigned to have experienced and even to understand what outsiders would not have any part in.

In his efforts at explaining the meaning of baptism, Ambrose draws on a broad range of biblical metaphors, most of which were familiar from life in general in antiquity. ${ }^{27}$ In this, he is quite conventional, but his varied use of wellknown metaphors would probably have broad appeal. In particular, he makes use of two metaphorical domains, that of rebirth (Myst. 5; 59) and that of death/ new life (Myst. 21; Sacr. 2.23; 3.2; also 6.8), and he also weaves the two together (Sacr. 3.2). The former metaphor, which had a long and solid tradition behind it, took its point of departure in John 3:5-8 (new birth through water and Spirit). The latter, which had its main background in Romans 6:3-11 (death to sin and unity with Christ in his death and burial, and in resurrection and eternal life), seems to have come more into vogue during the fourth century. ${ }^{28}$ Ambrose elaborates this motif amply and quite creatively: he maintains that both death and new life are "for our good, for death is the end of sins and resurrection is the reformation of nature" (Sacr. 2.17). And the way human beings can both die and rise again in this life is through baptism. Since "the potentials of our life did not permit that we be covered with earth and rise again from earth", God made this possible through water which is "of earth", but which (unlike earth) cleans, "washes". Thus, says Ambrose, "the font is as a sepulchre" (Sacr. 2.19). ${ }^{29}$

In addition to and often in relation to these metaphors, Ambrose speaks of baptism in terms of purity, as being washed clean from defilement and being sanctified (Myst. 1; Sacr. 1.15-16; 3.7). This was made visible through the white garments that the neophytes wore during the Octave of Easter (Myst. 34). Ambrose also uses language from medicine: healing/cure (Myst. 23), and from the juridical sphere: fault/grace (Sacr. 1.12; 3.12), remission of sins (Myst. 21),

On the following, cf. also Ferguson, Baptism, 641-647. 
and justice (Sacr. 1.15). ${ }^{30}$ All these are metaphors found in the Bible in connection with conversion and baptism, but also metaphors that would reflect central concerns for people in late antiquity.

Again and again, Ambrose underscores the role of the Trinity in relation to baptism. Being a Christian is to have been baptized in the name of the Father, Son, and the Holy Spirit. This is shown in the Bible, not least in the baptism of Jesus (Myst. 24-28) and is underscored through the threefold confession of the Persons in the Trinity at baptism (Myst. 19-21; also Sacr. 1.18; 2.22).

A main point for Ambrose with regard to the nature of the sacraments is the relationship between what is visible and what is invisible. On several occasions, he remarks that the neophytes may think that what they meet in the ritual is of a trivial kind: what they experience are only human beings dressed up as clergy, ordinary water, ointment and the smell of incense (Myst. 17; 19). He argues at length that what the baptizands receive is far beyond what they can capture with their senses (Myst. 49-54; Sacr. 1.9-10; 4.13-25). In baptism, they are linked to a world of supreme quality, which is invisible and eternal as distinct from the visible and merely temporal world. ${ }^{31}$

This does not mean that Ambrose wants to turn the neophytes away from the temporal domain. Rather, both spheres have their place. Thus, he states that there can be no sacrament without both the visible element, water, and the invisible and operative word of God, which ultimately is Christ (Myst. 8; 22; Sacr. 1.15). The water is a sign of the presence of the Deity, and it is not the water that cleanses, but that which is given through it: grace (Myst. 17; 20). ${ }^{32}$ This is something that the unbelievers do not understand, but that the neophytes through their faith have seen (Myst. 22).

In baptism, then, the Christians have been made part of a domain which is inaccessible to others, and which goes beyond the world presented to the senses. In order to strengthen the neophytes in their identification with what they have been through, he admonishes them at the end of his exposition of baptism (Sacr. 3.12; also Myst. 27):

Do you also consider the eyes of your heart. You saw the things that are corporeal with corporeal eyes, but the things that are of the sacraments you were not yet

30 This is not so surprising, since Ambrose was especially trained in law, see also Sacr. 1.5.

31 During the middle 380's Ambrose read several Neo-Platonist writings (Plotinus and Porphyry in particular, but also Philo, whose Biblical exegesis was much influenced by Plato). However, both The Mysteries and The Sacraments show limited Neo-Platonic influence. Ambrose's insistence on the visible/invisible division of reality, which can be interpreted as such an influence, was a stock theme in contemporary philosophical and theological thinking. The degree of (Neo-)Platonic influence has been a much debated topic in research on Ambrose, see McLynN, Ambrose of Milan, xx-xxi, 240-42.

32 Ambrose develops on this particularly in connection with the Eucharist and holds a view that comes very close to the idea of transubstantiation, i.e. that the bread and wine when consecrated actually are transformed into the body and blood of Christ (Sacr. 4.15-20). 
able to see with the eyes of the heart. So, when you gave your name, he took mud and besmeared it over your eyes. ${ }^{33}$ What does this signify? That you confessed your sin, that you examined your conscience, that you performed penance for your sins, that is, that you recognize the lot of human generation. For, even if he who comes to baptism does not confess sin, nevertheless by this very fact he fulfils the confession of all sins, in that he seeks to be baptized and so as to be justified, that is so as to pass from fault to grace.

Interestingly, Ambrose here and in the following passage also emphasizes that baptism shows that all humans share the same lot: whether one has been baptized or not, none is without sin. Being a Christian thus also means being still fully human: "he who takes refuge in the baptism of Christ recognizes himself as human (agnoscit se hominem)" (Sacr. 3.13-14). However, as a Christian one has a remedy for sins committed after baptism, namely the Eucharist, which Ambrose, unlike many others, recommends that one should receive on a daily basis (Sacr. 4.26-29; 5.25). Clearly, Ambrose regarded this as a central means for preserving and strengthening the Christian identity which was established in baptism. ${ }^{34}$

\subsection{Use of the Bible}

A striking feature in both The Mysteries and The Sacraments is Ambrose's frequent and wide-ranging use of the Bible. In fact, almost all his illustrations (exempla, cf. Sacr. 4.17) are drawn from it. Thus, when he aims to display the meaning and implications of baptism, it is the world of the Bible that he places in front of his audience. Ambrose's interest in historical aspects appears limited, however. His intention is to show how biblical events point to - prefigure - Christian baptism; in these sources, at any rate, it is this that appears to give them their value.

Most of these prefigurations are from the Old Testament, but several are also from the New Testament. The way Ambrose presents them, especially in The Sacraments, shows a limited concern for chronological sequence. Obviously, his intention is to convey what the events tell about the Church and its sacraments. However, it is important for him to establish one historical matter: the early origin of the sacraments. In his view, baptism is prefigured already at the time of creation, in the mention of the waters and the Spirit (Gen 1:2; cf. Myst. 9;

33 This element of the rite has its biblical basis in John 9:6-7. Cf. also the aperitio ("opening of the ears") ceremony on Holy Saturday (Myst. 3-4; Sacr. 1.2-3), see Ferguson, Baptism, 636, with references.

34 For Ambrose, baptism was with few exceptions necessary in order to receive grace and salvation. The only exceptions were unbaptized martyrs who had undergone a "baptism of blood" or persons who had died prematurely, but who had witnessed an earnest desire to be baptized. In the case of infants who die unbaptized, he is more ambivalent: they may avoid punishment after death, but he doubts that they will be received into the Kingdom of Heaven. See Dudden, The Life and Times of St. Ambrose, 644 (vol. 2) for references to primary sources. 
also Sacr. 1.23). Similarly, the Eucharist was prefigured already in the manna in the desert, long before the Law of Moses and the time of the synagogue (Exod 16:13-15; cf. Myst. 44-45; Sacr. 4.9-11). Clearly, Ambrose's point is to show that the sacred rituals of Christianity live up to the ideals of longevity in classical antiquity - the older a phenomenon was shown to be, the more status and credibility it would have - and baptism could be traced back to the ultimate beginning, the first day of creation.

Certain biblical stories have a particularly central place in Ambrose's repertoire, as prefiguring various aspects of baptism. Almost all of them were among the most popular and well-known stories in early Christianity. Important examples are the waters and the Spirit in the creation story (Myst. 9); the flood and Noah's rescue in the ark (Myst. 10-11; Sacr. 1.23; 2.1); the exodus of the Israelites through the Red Sea (Myst. 12; Sacr. 1.19-21); the pillar of light and the cloud in the desert (Myst. 13; Sacr. 1.22); and the spring of Mara into which Moses put a piece of wood (Myst. 14; Sacr. 2.12-13). Also, the Holy of Holies of the temple in Jerusalem can be seen as prefiguring the Christian baptistery (Myst. 5; Sacr. 4.1-4).

Some of the biblical prefigurations are especially emphasized by Ambrose, and he develops them from typologies into more detailed allegorical narratives. This is particularly the case with the story about the healing of the Syrian Naaman in the river Jordan (2 Kgs. 5:1-14; see Myst. 16-21; Sacr. 1.13-14; 2.8-9); the healing angel at the pool of Bethesda (John 5:1-9; see Myst. 22-23; Sacr. 2.3-7); and the baptism of Jesus (John 1:32-34 par.; see Myst. 24-26; Sacr. 1.15-19). Ambrose's frequent use of the Song of Songs deserves special mention. He interprets it allegorically as referring to the sacraments in general (Myst. 55-58) and in particular to the ointment after baptism (Myst. 29-41).

Thus, Ambrose's broad use of the Bible and his play on central biblical narratives and metaphors, in combination with his appeal to both the intellect and the emotions - all this contributes to shaping a landscape in which the grand events of the biblical past are repeated, relived, and brought to a climax in the sacred rite which the neophytes have just experienced personally. ${ }^{35}$

\subsection{The Social Dimension}

Shaping identity is, as noted above, very much a matter of how a person or a group relates to the surrounding world, to "others", whether these are seen as allies or as antagonists. ${ }^{36}$ In Ambrose's preaching on baptism, we can observe that this is central to his approach. First, it is clear that he aims to strengthen the identity of the individual Christian. This is demonstrated in his description of

35 See McLynn, Ambrose of Milan, 237-40, for a similar view of Ambrose's preaching in general.

36 See ibid., 249-251 and chapter 6 on how Ambrose related to a number of personal "others", i.e. some of his friends and foes. 
the act of baptism: when asked at the font whether they "renounce the devil and his works", the baptizands were to answer on their own behalf: "I do renounce" (Sacr. 1.5). Similarly, they were to profess their faith in the Persons of the Trinity, by repeating three times: "I do believe" (Sacr. 2.20-22). In addition, Ambrose urges them to examine their heart: to confess sin, examine one's conscience, and perform penance (Sacr. 3.12). The focus on the individual is also evident in the praxis of handing in their names at the enrolment for baptism (Sacr. 3.12).$^{37}$ In these ways, each and all were challenged to take responsibility for their own life and standing vis-à-vis the world and the ultimate forces of good and evil.

At the same time, Ambrose strongly underscores that baptism unites each believer with all other Christians, and with the church. Unlike the healing only of individuals by the angel at Bethesda (John 5:4), all are included in Christian baptism: "Then one person was cured, now all are healed, or rather a single person who is the Christian people" (Myst. 23; also Sacr. 2.5). Ambrose's emphasis on the collective is also displayed in his general rhetoric: he speaks to his audience in the plural "you", and occasionally addresses them as "most beloved brethren" (Sacr. 3.15). The balancing of individual Christian identity and identification with the collective of the other faithful appears to be a conscious strategy of his - it is even sanctioned by Christ. This he underscores in an exegesis of Song of Songs in which he repeats the point twice: "You have come to the altar; the Lord Jesus calls you - both your soul and the Church ...", and a little later "on account of the following - both the condition of the man and the Church - your soul sees that it is cleansed of all sins ..." (Sacr. 5.5, 7).

Although Ambrose usually speaks of Christians in general, he also on some occasions stresses hierarchy. The ecclesial ministers at baptism - bishop, presbyter, and deacon - are given special attention. They are, with scriptural support for instance from Malachi 2:7, accorded high importance. Ambrose sees them as angelic-like mediators between God and humans, and states about the presbyter: "There is no mistake, there is no gainsaying it: he is the angel who announces the reign of Christ, who announces eternal life. You must think of him in terms not of his outward appearance but of his office. Reflect on what he gave you, ponder his function and recognize his position" (Myst. 6; also Sacr. $1.6-7 ; 6.26)$. Although Ambrose clearly gives a high status to the ecclesial personnel, he is careful to state that this is due to their functions, not to their merits - and he is not blind to the varying quality of these merits (Myst. 27). ${ }^{38}$

An important aspect of the neophytes' relation to their surroundings is that they must renounce the world with its wantonness and pleasures (Myst. 5; Sacr. 1.5-6). In this, Ambrose's ascetic leanings shine through, but without being stressed. As noted above, the Christians have a struggle against the devil and

37 Sacr. 3.12; cf. also Augustine, Serm. 132.

38 In his emphasis on function, not merit, he may have the Donatists in mind. But he does not mention them elsewhere in these works. 
the world. And a principal instrument in this struggle is the fact that they have been anointed athletes of Christ (Sacr. 1.4). Through this they will succeed in the contest and win the crown and reward of eternal life. Ambrose does not describe this as a fight against others, however, but more as a mode of self-exercise and self-denial.

On a number of occasions, Ambrose also refers critically to outsiders. A central aim of this is obviously to define and strengthen the Christian identity of his neophyte audience. He marks boundaries towards several groups, but the degree of polemic is clearly varying. Most of this material is to be found in The Sacraments, since this work is much longer and less polished than The Mysteries; but similar strategies are also reflected in the latter.

Ambrose is the least reserved towards other Christians, although there is clearly a sting in what he has to say about different practices. As for the celebration of the Eucharist, he is critical of following the practice of the Eastern churches and taking the sacrament only once a year - which some in his audience seem to do. Since the Eucharist is the best remedy against sin, it should be taken every day; this is in his interpretation what is meant by "give us this day our daily bread" in the Lord's Prayer (Sacr. 5.24-26).

On two occasions Ambrose also mentions the practice of the church in Rome, the traditional centre of Christianity, but with Milan as a contemporary strong competitor. One has to do with Christian self-designation. At the very start of The Sacraments he gives his support to the Roman practice of terming the Christians "the faithful" (fideles). Still, he seems to do so with an air of critique: "Thus, even in Rome they are called 'the faithful' who have been baptized, and our father Abraham was justified by faith, not by works" (Sacr. 1.1, ideo et Romae).

The other occasion is when he comments on the ceremony of footwashing, which had John 13 as its model and followed immediately after the baptism and anointing. This was a custom which they did not have in Rome. ${ }^{39}$ And even though Ambrose excuses them for this, he also holds that the practice in Milan is more in accordance with the Bible, and declares with quite a bit of confidence on behalf of himself and his congregation: "So I say this, not that I may rebuke others, but that I may commend my own ceremonies. In all things I desire to follow the Church in Rome, yet we, too, have human feeling; what is preserved more rightly elsewhere we, too, preserve more rightly" (Sacr. 3.5).

Ambrose is less diplomatic towards more direct competitors. With Arians in view, with whom the Catholics in Milan had been at odds during the whole of the preceding decade, he strongly emphasizes the equality of the three Per-

39 The evidence for the rite is limited elsewhere too, see JoHnson, The Rites of Christian Initiation, 171-175, 199 (synoptic chart), 240-245. 
sons in the Trinity. ${ }^{40}$ In one instance, he explicitly refers to the Arians and criticizes them for their view on the Holy Spirit (Sacr. 6.10). And he clearly has them in mind when he insistently exhorts the neophytes (Myst. 28; also 20-21; Sacr. 1.17-19):

Remember how you responded, that you believe in the Father, that you believe in the Son, that you believe in the Holy Spirit. This is not to be understood as: I believe in a greater, a lesser and a least. Rather, with the same care that you exercise in your use of words you are constrained to believe in the Son just as you believe in the Father and to believe in the Spirit just as you believe in the Son.

Ambrose's most frequent marking of boundaries, however, is against Judaism. Although he is not known to have been in conflict with Jews in Milan, Judaism appears at the time to have been felt as a more general problem or threat. A reflection of this is that when a synagogue in a small town on the banks of the Euphrates in 388 had been burned down, allegedly at the instigation of the town's bishop, Ambrose harshly and uncompromisingly supported the burning, even against the emperor who wanted it rebuilt at the expense of the church. ${ }^{41}$

In The Sacraments and The Mysteries, Ambrose criticizes Jews for performing false and "superfluous" baptisms, they "baptize pots and cups (cf. Mark 7:4), as if insensible things could receive either blame or grace" (Sacr. 2.2; Myst. 23). Furthermore, the Christian sacraments are - as already noted - older than the synagogue and Judaism. But not only that: they are also better and more divine (Myst. 47-49; Sacr. 1.11-12). He reproaches the people of the Jews for murmuring unduly in the desert (Sacr. 1.21), and also blames them for insincere prayer: Christians should not pray like them since "'this people honours me with their lips, but their heart is far from me'. Do not, then, let your prayer proceed from the lips alone. Assert it with your whole mind, enter the recesses of your breast, go in wholly" (Sacr. 6.13)..$^{42}$ Compared to Ambrose's attitudes elsewhere, however, his polemic here is not sharp, and his criticism seems based on New Testament material more than on any contemporary familiarity with Jewish practices. The criticism Ambrose launches here, though it clearly remains problematic, nonetheless seems intended more as a strengthening of in-group identity than as an attack on Judaism or Jews.

Finally, but only in passing, Ambrose hints at pagan opponents. Like the Jews they perform baptisms, but such acts "are not baptism. They are baths, but they cannot be baptisms" (Sacr. 2.2). He may also, in an interpretation of Song of

\footnotetext{
40 The peak times in his encounters with the Arians were in 385-386 (the Arian dowager empress Justina) and in 389-390 (the emperor's massacre in Thessalonica). On Ambrose's conflict with the Arians, see D. H. Williams, Ambrose of Milan and the End of the Nicene-Arian Conflicts.

41 See McLynn, Ambrose of Milan, esp. 298-308; Ramsey, Ambrose, 34-35.

42 I have slightly modernized the biblical quotation.
} 
Songs 8:7, indicate that they are to be blamed for persecuting Christians (Myst. 41). All in all, however, his anti-Gentile polemic emerges as insignificant.

In the texts, then, Ambrose clearly employs his criticism of others in order to shape the Christian identity of the neophytes. In the case of the Arians, his critique has the intention of equipping his flock against what he saw as an actual, serious threat. In the case of Judaism, his warnings emerge as more conventional, as a means of showing how Christianity and Christian beliefs have surpassed those of the old covenant.

\section{Augustine’s Easter Sermones}

In The Mysteries and The Sacraments we have observed how Ambrose consciously employs a variety of means in his efforts at chiselling out a new, Christian identity for his audience - in fact, we have seen him utilizing elements from all the dimensions of religion described by Smart, and in ways that aim at making baptism an event as multivalent as possible for the participants.

Despite the abundance of writings that Augustine has left to posterity, there is nothing comparable to the succinct treatment of baptism and Christian identity that we find in Ambrose. Augustine has no complete expositions on the sacraments, although he deals extensively with baptism in many of his theological controversies, for example in his conflicts with the Donatists, the Pelagians, and Julian of Eclanum. ${ }^{43}$ It is also striking how little he reflects on the issue in the numerous writings from around the time of his own baptism, for example in the Cassiciacum dialogues. ${ }^{44}$ Thus, when we look for material in Augustine on our topic, the closest parallel to Ambrose's writings as regards intention and occasion are his Easter sermons. ${ }^{45}$ Of special relevance are the sermons Augustine preached from the Easter vigil, immediately after the act of baptism, and during the whole of the Octave of Easter, i.e. until the Sunday after. As in Milan, it was customary in Hippo that the neophytes this week were present at daily church services, still dressed in the white robes in which they had been baptized. ${ }^{46}$

Augustine's Sermones 219-229Z constitute a majority of the Easter sermons. They consist of about forty-five mostly brief speeches, some very brief, held at

43 See the references in Harmless, "Baptism," 90-91; Finn, Early Christian Baptism, 148, 164 171; M. A. Tilley, "Baptismo, De," 92.

44 What he says about baptism there is vague and conventional, see e.g. Beat. 3.18; Ord. 2.5.16; $2.9 .27 ; 2.17 .46$.

45 Some of his catechetical writings, such as Catechizing the Uninstructed and Enchiridion on Faith, Hope, and Love (esp. chs. 42-52), also contain relevant material, but are not so closely linked to the ritual of baptism as are the sermons. Thus, they will not be dealt with here.

46 For a survey of all of Augustine's Easter Vigil sermons and of his sermons mentioning the neophytes, see Harmless, Augustine and the Catechumenate, 340-342. 
differing times over the years, and partly also at varying places. ${ }^{47}$ For this reason, they deal with baptism less systematically and also in less detail than Ambrose does. Instead, Augustine focuses on other topics, frequently on exhortations to keep vigil (e.g. Serm. 219-222) and to avoid and overcome temptation (Serm. $223 \mathrm{E}-\mathrm{G})$. In many sermons he takes his point of departure in New Testament passages about Christ's resurrection and reflects on its meaning and implications (e.g. Serm. 223B-D; 229A-O), only occasionally linking it to baptism. ${ }^{48}$ Thus, the sacrament is mostly touched on in indirect and scattered remarks, and the material is somewhat more difficult to relate to our topic than was the case with Ambrose. In what follows, it will be inexpedient to make a broad analysis of the sources. Instead, I shall present the texts with special reference to what has been said about Ambrose above, and with an eye to similarities and differences. For the sake of simplicity, the sermons will usually be referred to only by number and letter.

\section{Augustine on Baptism and Christian Identity}

Like Ambrose, Augustine in his sermons clearly aims at influencing his addressees' self-understanding and their perceptions of Christian beliefs and of the world. In this, he too moves within all the seven dimensions sketched above. On many points Ambrose and Augustine share similar strategies. For example, Augustine often refers to elements in the ritual of baptism, and to the rites before and after, such as the kiss of peace, chrism, and practices in the Eucharist (e.g. $226 ; 227 ; 228.3 ; 229.3)$. He also frequently mentions the reading of biblical texts and the singing of psalms and hymns (e.g. 229B.2). Theological reflection and use of the Bible play a significant part too, as does the social dimension; but - as we shall see - there are also significant differences in these respects.

What should be pointed out here at the outset, however, is Augustine's stronger focus on the experiential and ethical dimensions. More than Ambrose, Augustine appears to appeal to emotions, for example in his many exhortations to keep vigil, in his frequent mention of feelings, such as grief and joy (e.g. 221.1), and in his often repeated contrasting of light and darkness (e.g. 221.4). Generally, he appears to have a more psychologising and less intellectualistic

47 For a chronological table, see Sermons III/6 (The Works of St. Augustine), 346-350. There is not much on baptism in sermons related to the time before baptism, e.g. in sermons on the handing over of the Creed, such as Serm. 212-215. For an overview, see the chart in HARMLEss, Augustine and the Catechumenate, 191-192.

48 Since many of the sermons are difficult to date and span more than three decades, it is not possible here to take into account how they relate to different phases in Augustine's life and controversies, or what changes or developments may have taken place in his preaching on baptism. 
approach in his sermons than Ambrose. ${ }^{49}$ Similarly, Augustine spends more energy and time on moral issues. His appeals to right living are frequent, and he is also more specific in his advice to the neophytes, and to his audience in general. However, these are features to which I return in more detail below.

\subsection{Theology of Baptism}

It is clear that Augustine employs many of the same metaphors as Ambrose to explain the meaning and implications of baptism - substantially, his main domains of metaphor too are that of death/new life and of rebirth (see section $\$ 5.1$. above). Baptism is seen as participating in the death and life in Christ (228A). It is not only a water bath, it is at the same time a burial with Christ (229A.1) what happens is far more than what is visible to the eye, as also Ambrose repeatedly states. And Christ's resurrection is the "sacrament, the model, of the new life" (229E.3). In the same passage, Augustine describes the old and the new life in dramatic contrasts:

You believed, you were baptized, your old life died, slain on the cross, buried in baptism. The old, which you lived so badly, has been buried; let the new life arise. Live a good life; live in such a way that you may live; live in such a way that when you die, you don't die.

Like Ambrose, Augustine frequently depicts baptism as a new birth, a rebirth and regeneration (223E.2; 224.1). The neophytes have "been born again of water and the Spirit" (228B.1), and as a new creation (226). It is also described in terms of holiness: the neophytes have been "sanctified by the blood of the crucified Lord" (223E.2). Moreover, they have become members of Christ (224.1). Baptism also means forgiveness of sins; indeed, absolutely all sins are forgiven - even the killing of Christ (229E.2).

On occasion, Augustine weaves together and embroiders rhetorically upon these metaphors, which all belong firmly within biblical and early Christian tradition. For example, he says of the neophytes (223.1),

outwardly clothed in white, inwardly cleansed and purified, the brilliance of their garments representing the splendor of their minds, [they] were once darkness, when the night of their sins was covering them. But now that they have been washed clean in the bath of amnesty, that they have been watered from the fountain of wisdom, that they have been bedewed with the light of justice, 'this is the day which the Lord has made; let us exult and rejoice in it' (Ps 228:24).

Like Ambrose, Augustine uses metaphors from the sphere of medicine. However, he elaborates more frequently on them: "Baptism is a great and divine sacrament, such a splendid and noble medicine ..." (228B.1). He can, for instance, describe

49 Augustine's appeal to the emotions and his way of using rhetoric in the sermons are analyzed and argued in detail in P. R. Kolbet, Augustine and the Cure of Souls. 
in considerable detail the post-baptismal life as a state in which a Christian has to avoid giving in to a wrong cure and instead to listen to the doctor's advice, with the wise physician being "Doctor Christ" (229E.3) - he is "the doctor by whom" the world "has been delivered" (219).

In spite of some differences in emphasis, Augustine so far follows in the steps of Ambrose as to how baptism is preached to the neophytes. Interestingly, however, he deviates in other ways more clearly from him, with a profile of his own. First, Augustine's focus on baptism and the new life following from it as something unmerited, as grace, has no obvious parallel in Ambrose, and thus appears to strike a distinctly Augustinian note. ${ }^{50}$ He addresses the newly baptized in this way (224.1):

Doesn't all talk and perception quite fail to grasp or express how gratuitous grace
has come your way, without any merits of yours preceding it? And that's why it's
grace, because it has been given gratis, gratuitously, freely. What grace? That you
should be the members of Christ the Son of God, that you too should be brothers
and sisters of the only Son. If he is the only Son, how can you be his brothers and
sisters, except that he is the only Son by nature, you are his brothers and sisters
by grace?

Moreover, Augustine is more specific about the consequences of baptism. Whereas Ambrose describes the new ways of life, the ethical dimension, in rather general terms, Augustine appears more intent on stressing the difference baptism makes and on giving more specific moral advice. He stresses that from the "form of the sacrament", i.e. from being baptized, must follow the "power of the sacrament", a good life, with Simon Magus as a warning example (229V; also 229U). ${ }^{51}$ In a brief sermon held at the end of the Octave of Easter, Augustine addresses the neophytes: "You that have been baptized, and today complete the sacramental ritual of your octave, must understand, to put it in a nutshell, that the significance of the circumcision of the flesh has been transferred to the circumcision of the heart" (260). He goes on to stress that they should live a new life, and not "stifle what has been reborn in you by leading bad lives". And he then uses the rest of the sermon to exhort to chastity, respectful relations between husbands and wives, honesty in business dealings, and the avoidance of lying and extravagance, summing it all up in the commandment to love one's neighbour (cf. also 224.2-3).

Finally, a conspicuous difference is that Augustine has little of the mystagogical interest characteristic of Ambrose. Although Augustine too can speak of baptism as a mystery, information about its form and meaning is not withheld until after baptism or kept secret from the uninitiated. For example, the

50 Grace is of course a central idea for Ambrose too, but he deals with it more in passing (e.g. Sacr. 1.15).

51 Some scholars question the authenticity of these sermons. 
petitioners are informed about these matters in advance $(56.11,13)$. And immediately after baptism, on Easter day, Augustine can remind the neophytes about what they have already learned about the sacraments (228B.1; also 223F.1; 228.3).

These differences appear to signal distinctive strategies with regard to the matter of Christian identity construction. Whereas Ambrose focuses more on the intellectual and exclusive aspects of the ritual of baptism, Augustine emphasizes the public, non-exclusive ("gratis"), and ethical aspects. In fact, what Augustine mediates about baptism in connection with the rite itself is marked less by theological concerns (cf. the doctrinal dimension) than in Ambrose, and more by appeal to other concerns. For example, he does not discuss the Trinity, which clearly was important for Ambrose in connection with baptism..$^{52}$ Similar kinds of differences between the two will also be seen in the following sections.

\subsection{Use of the Bible}

As we have noted, Augustine had learned much from Ambrose's use of the Bible. This can be clearly seen in the Easter sermons, although Augustine's allegorizing is generally more moderate. He also draws on some of the same biblical material. The creation story of Genesis 1 is frequently employed: the newly baptized are like the light of the creation, and also a new creation (e.g. 223A; 226). The exodus narrative in Exodus 13-17 is used in a similar manner: like Pharaoh's horsemen in the Red Sea, all past sins have been left behind, drowned and obliterated in baptism (223E.2). As with Ambrose, New Testament passages such as Romans 6 are central for Augustine (228A), and he also on several occasions discusses the Prologue of John (e.g. 225.4).

There are, however, considerable differences between the two. To some extent, this is due to the fact that Augustine's Easter sermons are briefer, more spontaneous, and more impressionistic than Ambrose's. Several of the vigil speeches, for example, are mainly concerned with exhortations to watch and pray $(219 ; 220)$, and to struggle against the powers of darkness, in particular the devil and his angels $(222 ; 224.2)$. Here, Augustine often takes his point of departure in texts such as Mark 14:38 (Jesus' vigil in Gethsemane) and 2 Corinthians 11:27 (Paul's frequent vigils). He also appears to keep closer to the customary lessons of the Easter Octave, such as the passion and resurrection stories of the gospels. ${ }^{53}$ Thus, his use of the Bible appears aimed less at the neophytes and more at the assembly in general; unlike what we see in Ambrose, the neophytes are not singled out as a group distinct from the rest.

52 Augustine does, however, deal with the relationship between the Father and the Son, see section 7.3 (and Serm. 229G.3-5).

53 See Harmless, Augustine and the Catechumenate, 344-345 (charts 18-19). 
The most striking difference from Ambrose, however, is that the idea of prefiguration plays a considerably smaller part in Augustine's exegesis. Ambrose utilized a broad spectre of biblical passages for this purpose, for example the Flood and the Naaman stories, and not least the Song of Songs. In Augustine such passages scarcely appear, and when a few of them do, he rarely elaborates upon them as anticipations of baptism, but rather employs them as a reservoir for allegorizing. And whereas it was very important for Ambrose to show that baptism was historically prefigured already at creation, Augustine does not make a point of this. He does not place the sacrament of baptism, and consequently the neophytes, as squarely within a scheme of prefiguration. Unlike Ambrose, he rarely refers to Old Testament texts, with the exception of the Psalms; instead, he cites and alludes to a great variety of New Testament passages. This does not mean that the historical dimension is of no interest to him: cf. his use of Genesis 1 (e.g. 223). Rather, it appears that Augustine's strategy for the shaping of Christian identity is more psychologically and existentially rooted, in that he particularly stresses the "before and after" status of the individual: in baptism, each believer has gone from darkness to light, from death to life (e.g. 226).

As with the theology of baptism, therefore, Augustine in his use of the Bible appears less interested than Ambrose in presenting a systematic or intellectual approach to baptism; instead, he relates in a more immediate way to the experiential and emotional sphere of his audience. This does of course not imply that he is theologically less refined than Ambrose, but rather that there are hermeneutical and homiletic differences between them in this context, in their strategies for shaping Christian identity.

\subsection{The Social Dimension}

Augustine's emphasis on the social implications of baptism makes it clear that this is a vital dimension in his strategy for shaping Christian identity. As with Ambrose, so too a central aim for Augustine is to strengthen the identity of the individual. The newly baptized are praised as being the "way the Lord has made" (223.1). He often exhorts them to leave their past behind and live a new life (e.g. 224.2 ; 226) - although Ambrose too urges the neophytes on this by referring to their wow made at baptism to renounce one's evil deeds and to believe in the Trinity (Sacr. 1.5-6; 2.20-22).

Like Ambrose, Augustine emphasizes that baptism unites the individual with other Christians. This was clearly important for Ambrose, but Augustine stresses it more, and in a number of ways. First, he frequently speaks of the newly baptized as members of Christ (224.1). The church is also called "your mother the light", visualized in the candles lit in the basilica at night during the vigil (222). Correspondingly, the neophytes are described as a "new offspring of 
the mother Church" (228.2), and as "freshly born children of a chaste mother; or rather ... children of a virgin mother", thus likening their birth to that of Christ (223.1).

Characteristic of Augustine, and rather differently from Ambrose, is the way in which he integrates the neophytes into the community at large. Instead of teaching them separately, he places them among the other, "older" Christians and addresses the audience as a whole. For example, he speaks of the church as a household (219). Frequently, and with intensity, he addresses them as his "dearly beloved" (e.g. 229E.3), as "brothers and sisters" (e.g. 221.4; 228.1), and even as "my brothers, my sons, my daughters, my sisters" (224.2).

This inclusive kind of address does not mean that he overlooks the neophytes or avoids making distinctions among the believers. On the contrary, he seems consciously to balance and nuance his address. He alternately turns to the neophytes and to the more mature, advising them how to behave and to relate to each other, and appealing to their joint responsibility towards one another (224.1; also 223.1-2; 228.1-2):

Today those who have been baptized in Christ and born again are to be mixed in with the people of God, now that the sacraments have been solemnly celebrated. Let me address my remarks to them, and also to you in them and them in you. Here you are, you have become members of Christ. ... So because you are members of Christ, I have some advice and suggestions for you. Those you are to be mixed in with should listen too. I really fear for you today ...

The older are to support and be models for the neophytes, and they for their part are to turn to the good among the faithful, not to those who live bad lives (223.2). On several occasions Augustine exhorts them to be discerning about this, and he speaks of the church as a threshing floor with both grain and chaff, as a mixture of many kinds of humans (e.g. 224.1). ${ }^{54}$ Unlike Ambrose, who says little about the threats against true Christian identity that can arise internally, Augustine envisions many dangers, and warns the neophytes repeatedly about this (e.g. 224.3; 228.2-3). However, there is a potential for transformation and improvement even for the bad ones, as the history of the church has shown (223.2) ${ }^{55}$ Consequently, he goes on to admonish (223.2),

[s]o then, dearly beloved, if you are good, you must put up with the bad; if you are bad, you must imitate the good. The fact is, on the threshing-floor grains can degenerate into chaff, and again grains can be resurrected from the chaff ... Listen to me, grains; listen to me, those of you who are what I desire you to be ... Let the husks listen to me too ... Let God's patience stand you in good stead ...

54 See ibid., 343.

55 Serm. 2290.4 gives an interesting example of how community discipline could be handled within Augustine's own setting: he tells about a man whom he himself had pointed out as an Arian and Anomoean, but who had then very quickly decided to become a Catholic again. 
Whereas Ambrose clearly ascribes a high status to the clergy and other ecclesial personnel, Augustine has a less hierarchical approach. Not only the clergy have been entrusted with the keys of Peter to bind and loose on earth and in heaven (Matt 18:18). Thus, according to Augustine, after Peter passed away (229N.2),

who binds, who looses? I make bold to say, we too have the keys. And what am I to say? That it is only we who bind, only we who loose? No, you also bind, you also loose. Anybody who's bound, you see, is barred from your society; and when he's barred from your society, he's bound by you; and when he's reconciled he's loosed by you, because you too plead with God for him.

Although Augustine does not elaborate here on what is implied by binding and loosing, his fairly egalitarian view of the relations among neophytes, the more mature, and the leaders is clear. This in turn also corresponds well to his nonmystagogical baptism theology.

Like Ambrose, Augustine on several occasions employs the concept of the "other" as a means in the construction and strengthening of the identity of those inside the flock. His polemic can be just as sharp as Ambrose's, and aims at some of the same outsiders. But since Augustine's focus is less exclusively on the neophytes, his critique is less tied up with the issue of baptism, and seems - with some notable exceptions - to be of a more general kind. This does not mean, however, that he focuses little on the "other", or that he is necessarily less specific in his critique than Ambrose. In one interesting instance, he lists - in what looks like a pithy rhetorical formula - a "trinity" of outsiders whom he clearly regards as main opponents. In warning the community against internal hazards, he comments: "I really fear for you today, not so much from the pagans, not so much from the Jews, not so much from the heretics, as from bad Catholics" (224.1). In addition to dangers coming from the inside, it is clear that external threats too are to be reckoned with. Among such more or less deviant Christian groups, "heretics", he explicitly mentions Arians (225.1, 4; 229G.3-5), Sabellians (229G.3-5), and Manicheans (229J.1), and also alludes occasionally to them and others, for example the Donatists (e.g. 219; 225.1; 229.2). But his critique of these groups is mostly brief and not very specific, and is not related to baptism. ${ }^{56}$

Pagans are mentioned in just a few instances. Once they are criticized together with the Jews: the Easter vigil "displays the Christian peoples in all their serried ranks; it confounds the darkness of the Jews; it throws down the idols of the pagans" (220). The most elaborate discussion with a pagan view is an imagined discussion between himself (an "I") and a pagan about where God can

56 Serm. 229G.3-5 has a discussion with the Arians and Sabellians on the relationship between the Father and the Son, and at the end also about the Trinity. The sermon clearly intends to teach the in-house believers about how to relate to these views, but Augustine does not link this topic with baptism or with the neophytes. 
be found (223A.4-5). ${ }^{57}$ Augustine's aim is evidently to teach his audience about how to deal with an objection of a philosophical nature. However, he does not in any way link the issue with baptism or with the neophytes.

By far the most conspicuous and gross polemic in Augustine's Easter sermons is against Jews. We find this on several occasions. It was, for example, "the purpose of the Jews in killing Christ ... to obliterate his memory from the earth" and still "the world does not forget their crime" (223B.1). Their crime against Christ was even prophesied in the Psalms (223C). While Christians at Easter are celebrating the ultimate sacrifice of Christ, "the Jews, as opponents of this splendid manifestation of light, are still carrying on with various nocturnal foreshadowings of theirs," celebrating a false Pasch (229C.1).

These harsh comments are to some extent balanced by his description of what happened at Pentecost, when the Jews who repented and believed had all their sins "forgiven them, even to the extent of the very deed being forgiven by which Christ had been slain". These Jews "who had killed Christ", but who grieved and believed "and so came to life again", also serve as admonitory examples. In Augustine's words: "The faithful understand what I have just said, and these neophytes, because they have already drunk it [the blood of Christ at the Eucharist]. So those of you who have not yet drunk should hurry up and drink, so that your minds may be opened" (229I.3). Augustine had only limited contact with Jewish milieus of his time and his attitudes should be understood on the basis of his interpretation of the Bible and earlier Christian tradition..$^{58}$ Thus, the main function of these statements is to employ Jews as a group of "others" in order to define the beliefs and strengthen the identity of the Christians themselves, and also to exalt the neophytes as ideals for less repentant believers.

From this we can observe that Augustine makes use of a variety of socio-religious "others", both in- and out-groups, in his strategy for shaping Christian identity. This, including his criticism of Jews, is very much on a level with Ambrose's approach. On one important point, however, Augustine configures the social dimension differently: he describes the internal threats as more dangerous than those from the outside. Those against whom new Christians should be the most on guard are other Catholics, namely those who live bad lives. Again, this highlights the ethical thrust which Augustine puts into his teaching of the neophytes about the implications of their baptism.

57 The discussion is similar to that of Civ. 1.29.

58 Augustine's view on Jews and Judaism has been much studied and discussed. In recent research, he is regarded as more positive and balanced in his attitudes than many of his contemporaries, not least through his "witness doctrine"; see M. Signer, "Jews and Judaism," 470-474, with many bibliographical references. 


\section{Baptism and Christian Identity in Ambrose and Augustine: Final Reflections}

In the texts quoted at the start of this chapter, the baptistery poem and the Confessiones passage, I noted their shared focus on baptism as an existential turning point for the persons involved. This impression has been strengthened in our study of the other sources: for both Ambrose and Augustine, baptism plays a crucial part in their understanding of Christian identity and in their strategies for shaping and strengthening such an identity.

The analysis has shown that there are many similarities in how the two elaborate this, not least in their theological understanding and in how they employ baptism as a boundary marker for the neophytes vis-à-vis their past or in relation to outsiders. But the profiles of Ambrose and Augustine also differ in important respects. One indication of this is the stronger emphasis of the former on the intellect and of the latter on the emotions. This too is in fact signalled in the two texts above: whereas Ambrose's poem is theological and didactic (baptism is about "the kingdom and counsel of God" and "the glory of righteousness"), Augustine's description treats of experience and feelings (how "copiously I wept" and "how intensely was I moved"). Although the point should not be overstated, Ambrose can - rhetorically speaking - be said to appeal more to logos, Augustine more to pathos. ${ }^{59}$ A second indication of differences in their profiles is Ambrose's focus on general formation, with Augustine stressing more the practical, moral implications of baptism. And a final example are Ambrose's more "esoteric" and "hierarchic" ideas about how Christian identity should be expressed, and Augustine's more "public" and "egalitarian" view - although I do not imply a value judgment by using these epithets.

What did the Christian identity Ambrose and Augustine were aiming at, look like? By analyzing some of the means that they employed in their construction work, I have tried to elicit a few characteristic features of this identity. To pursue their ideas about this in more detail has not been possible here, and even less to consider how these ideas can have been appropriated by their flocks. The striking point which emerges in the material is the comprehensive nature of the two bishops' strategies. It is fascinating from a modern point of view - cf. Smart's dimensions of religion - to observe how Ambrose and Augustine in their practices and preaching on baptism made use of the whole scale of tools available for the construction of religious identity. Their approach - how they

59 In a general reflection on Ambrose's preaching McLynn, Ambrose of Milan, 247-248 suggests that this is due to that "an imperial capital afforded a more sophisticated audience than a Numidian municipality". This may to some extent be true, although I am not so sure that the audience in Hippo would be that much less sophisticated than those in Milan. In my view, differences in the personality and temperament of Ambrose and Augustine themselves can better explain the differences in their rhetorical strategies. 
engaged thinking and emotions, employed narratives and rituals, structured time and space, balanced individual and social concerns - bears the marks of a broadly developed, all-encompassing, and highly integrated view of the world ${ }^{60}$ In the form presented by Ambrose and Augustine, Christianity could offer its adherents a complete set of building blocks for personal and communal identity. No other religious or philosophical option on the ancient market, perhaps with the exception of Judaism, would match this. Instead, the common mentality and praxis had been to combine eclectically elements from different systems, for instance to acquire social status by taking part in a public cult, get emotional stimulus in a mystery ritual, and find moral guidance in a particular philosophy. Until the fourth century, not even the Christian religion could live up to this. It was probably only with the developments within dogma and art, church building and ecclesial organization during this period that such comprehensiveness was reached. Indeed, a main reason why Christianity enjoyed such success at this time may have been the full-blown, "holistic", shape it attained.

In Ambrose's and Augustine's approaches to baptism we see this in crystallized form. ${ }^{61}$ In the act of baptism, we sense how they consciously and creatively - each in his own characteristic way - made use of the manifold dimensions of religion to construct a new, distinctively Christian identity in their followers, an identity which related to all aspects of their lives. At a point of time in which a significantly growing number of people - adults, children, and even infants - underwent baptism, the practices and preaching of Ambrose, Augustine and others like them on baptism contributed significantly to the transformation of the world of classical antiquity into a new era in the West, that of the Christian Middle Ages.

60 Johnson, "Christian Initiation," 703-706 holds that one reason why the church in the century after Nicaea adopted a variety of ceremonial acts in connection with baptism was "to ensure that its sacramental life would continue to have some kind of integrity when, in a changed social and cultural context, in which Christianity was now favoured by the Emperor, authentic conversion and properly motivated desire to enter the Christian community could no longer be assumed automatically" (704). In my opinion, it should rather be seen - cf. the "holistic" strategy for the construction of Christian identity indicated below - as a way of broadening and strengthening the personal involvement of the baptizands, and not as a way of discouraging or scaring them away, as Johnson seems to imply.

61 Riley, Christian Initiation, 454, holds that Ambrose's special contribution to the baptismal liturgy (as compared to Cyril, Chrysostom, and Theodore) is his "redemption of the imagination". 


\section{Bibliography}

\section{Primary SOURCES}

Ambroise de Milan, Des Sacrements, Des Mystères, Explication du Symbole (SC 25), Paris: Les Éditions du Cerf 1961.

Ambrose, Theological and Dogmatic Works (Fathers of the Church 44), Washington, D.C.: The Catholic University of America Press 1963.

Augustine, Sermons III/6 (184-229Z) on the Liturgical Seasons (The Works of Saint Augustine: A Translation for the $21^{\text {st }}$ Century), New Rochelle, N.Y.: New City 1993.

Augustine, Sermons III/7 (230-272B) on the Liturgical Seasons (The Works of Saint Augustine: A Translation for the $21^{\text {st }}$ Century), New Rochelle, N.Y.: New City 1993.

Augustine, The Confessions (The Works of Saint Augustine: A Translation for the $21^{\text {st }}$ Century), Hyde Park, N.Y.: New City 1997.

Corpus Christianorum. Series Latina 27 (CCL), Turnhout: Brepols 1981 (Augustine, The Confessions).

De Rossi, G. B., Inscriptiones christianae urbis Romae (Vol. 2/1), Roma: Ex officina libraria Philippi Cuggiani 1888.

Patrologiae Cursus Completus, Series Latina 38 (PL; edited by J.-P. Migne), Paris: Migne 1844-1864 (Augustine, Sermons).

Patrologiae Cursus Completus, Series Latina 39 (PL; edited by J.-P. Migne), Paris: Migne 1844-1864 (Augustine, Sermons).

Supplement to the Patrologiae Cursus Completus, Series Latina 2 (PL Supp; edited by A. Hamman), Paris: Éditions Garnier Frères 1958-1974 (Augustine, Sermons).

The Holy Bible (New Revised Standard Version), Nashville, Tenn.: Thomas Nelson 1990.

\section{SECONDARY Literature}

AasgaArd, R., "Among Gentiles, Jews, and Christians: Formation of Christian Identity in Melito of Sardis," in: R. Ascough (ed.), Religious Rivalries and the Struggle for Success in Sardis and Smyrna (ESCJ), Waterloo: Wilfred Laurier University Press 2005, 156-174, 280-284. 
Bell, S./Hansen, I. L., Role Models in the Roman World: Identity and Assimilation (Memoirs of the American Academy in Rome, Suppl. Vol. 7), Ann Arbor, Mich.: The University of Michigan Press 2008.

Bradshaw, P. F., "Diem baptismo sollemniorem': Initiation and Easter in Christian Antiquity," in: M. E. Johnson (ed.), Living Water, Sealing Spirit: Readings on Christian Initiation (A Pueblo Book), Collegeville, Minn.: Liturgical 1995, 137-147.

Burns, J. P., “Ambrose Preaching to Augustine: The Shaping of Faith," in: J. C. Schnaubelt/F. van Fleteren (eds.), Collectanea Augustiniana, Augustine: "Second Founder of Faith", New York et al.: Peter Lang 1990, 373-386.

Burrus, V. (ed.), Late Ancient Christianity (A People's History of Christianity, Volume 2), Minneapolis, Minn.: Fortress 2005.

Dudden, F. H., The Life and Times of St. Ambrose (volume II), Oxford: Clarendon 1935.

Ferguson, E., Baptism in the Early Church, History, Theology, and Liturgy in the First Five Centuries, Grand Rapids, Mich.: Eerdmans 2009.

Finn, TH. M., Early Christian Baptism and the Catechumenate: Italy, North Africa, and Egypt (Message of the Fathers of the Church 6), Collegeville, Minn.: Liturgical 1992.

Fitzgerald, A. D. (ed.), Augustine through the Ages: An Encyclopedia, Grand Rapids, Mich./Cambridge, U.K.: Eerdmans 1999.

Harmless, W., “Baptism,” in: A. D. Fitzgerald (ed.), Augustine through the Ages: An Encyclopedia, Grand Rapids, Mich./Cambridge, U.K.: Eerdmans 1999, 84-91.

- Augustine and the Catechumenate (A Pueblo Book), Collegeville, Minn.: Liturgical 1995.

Harrison, S., "Autobiographical Identity and Philosophical Past in Augustine's Dialogue De Libero Arbitrio," in R. Miles (ed.), Constructing Identities in Late Antiquity, London and New York: Routledge 1999, 133-158.

Harvey, S. A./Hunter, D. G. (eds.), The Oxford Handbook of Early Christian Studies, Oxford: Oxford University Press 2008.

Jensen, R. M., “Baptismal Rites and Architecture," in: V. Burrus (ed.), Late Ancient Christianity (A People's History of Christianity, Volume 2), Minneapolis, Minn.: Fortress 2005, 117-144. 
Johnson, M. E., “Christian Initiation,” in: S. A. Harvey/D. G. Hunter (eds.), The Oxford Handbook of Early Christian Studies, Oxford: Oxford University Press 2008, 693-710.

- The Rites of Christian Initiation: Their Evolution and Interpretation (A Pueblo Book), Collegeville, Minn.: Liturgical 2007.

Kolbet, P. R., Augustine and the Cure of Souls: Revising a Classical Ideal (Christianity and Judaism in antiquity 17), Notre Dame, Ind.: University of Notre Dame Press 2010.

Mayer, W., "Homiletics", in: S. A. Harvey/D. G. Hunter (eds.), The Oxford Handbook of Early Christian Studies, 565-583.

McLynn, N. B., Ambrose of Milan: Church and Court in a Christian Capital, Berkeley/Los Angeles/London: University of California Press 1994.

- "Ambrose of Milan," in: A. D. Fitzgerald (ed.), Augustine through the Ages: An Encyclopedia, Grand Rapids, Mich./Cambridge, U.K.: Eerdmans 1999, 17-19.

Miles, R. (ed.), Constructing Identities in Late Antiquity, London and New York: Routledge 1999.

- "Introduction: Constructing Identities in late antiquity," in: IDEM (ed.), Constructing Identities in Late Antiquity, London and New York: Routledge 1999, 1-15.

Ramsey, B., Ambrose (The Early Church Fathers), London and New York: Routledge 1997.

Riley, H. M., Christian Initiation: A Comparative Study of the Interpretation of the Baptismal Liturgy in the Mystagogical Writings of Cyril of Jerusalem, John Chrysostom, Theodore of Mopsuestia and Ambrose of Milan, Washington, D.C.: The Catholic University of America Press 1974.

Rousseau, Ph., "Augustine and Ambrose: The Loyalty and Singlemindedness of a Disciple," in: Augustiniana 27 (1977) 151-165.

Signer, M., "Jews and Judaism," in: A. D. Fitzgerald (ed.), Augustine through the Ages: An Encyclopedia, Grand Rapids, Mich./Cambridge, U.K.: Eerdmans 1999, 470-174.

Smart, N., The World's Religions: Old Traditions and Modern Transformations, Cambridge: Cambridge University Press 1989.

Tilley, M. A., “Baptismo, De, in: A. D. Fitzgerald (ed.), Augustine through the Ages: An Encyclopedia, Grand Rapids, Mich./Cambridge, U.K.: Eerdmans 1999, 91-92. 
Williams, D. H., Ambrose of Milan and the End of the Nicene-Arian Conflicts, Oxford: Clarendon 1995. 